\title{
A SYMPOSIUM OF CRITICAL LEGAL STUDIES
}

\author{
INTRODUCTION*
}

\author{
JAMES BOYLE**
}

Recently there has been a great deal of loose talk and brouhaha about critical legal studies. Several symposia have been devoted to the distinctly unplayful task of defining this mysterious animal. This Symposium is not one of them. Instead it is a collection of Articles about some of the subjects dear to the hearts of critical legal scholars, a collection which reflects the diversity of methods and objectives that are subsumed under the vague label of "critical legal scholarship."1

* So here it is. All of the themes beloved of critical legal scholars are represented-the undermining of false necessity, the idea that legal interpretation is not, and could not be, objective, the application of feminist criticism to an intellectual field which has been viewed for a long time as inherently "male," the politics of the classroom, the effect of reification in legal doctrine and economic theory, and the empowerment of students, the contingency of social constructs-and so on, and so on. "It's turtles all the way down," as the amateur cosmologist said to William James.

** (C) 1985 James Boyle

1. All of the Articles in this Symposium, with the exception of those by Mary Joe Frug and Duncan Kennedy, were produced in a seminar which went by the unprepossessing name of "Modern Legal Theory." Although my name appeared on the course catalogue as the teacher of this seminar, it was in fact taught jointly by all of the people in the class. The students in the seminar had all taken my Jurisprudence course and they were egging me on to put together an advanced seminar that would go deeper into the roots of the legal theories we had discussed in the Jurisprudence class, and would also allow us to practice what I had been preaching about the desirability of nonhierarchical teaching and learning. Each person would pick a topic, prepare reading materials on it, teach it to (or with) the class, and finally write an article on it. We would put together a symposium out of the works produced, invite the participation of a few outside authors, and offer the resulting collection to a law review. I thought that this method might help us to get around the implicit denigration of all forms of student-generated scholarship apart from notes, comments and analyses of what the Supreme Court has been up to. It seems almost impossible to get any kind of original scholarly work published when you are a student, unless your writing fits neatly into one of the aforementioned categories. Even critical legal studies symposia, always full of references to the disempowerment of students, hardly ever have articles by students themselves.

Of the seminar itself, there is too much to say. We studied feminism, structuralism, marxism, legal realism, and all of those things again with the requisite "post-s" and "neo-s." We read Levi-Strauss, Focault, Barthes, Wittgenstein, Derrida, Hobbes, Locke, Hegel, Nietzsche, 
The only trouble with the claim I have just made is that is seems to be denied by the contents page. How can one claim that there is anything common to all of the Articles presented here, given the eclectic range of subjects on which they concentrate? There is an Article about the suppression of the "female voice" in the classroom, about the cumulative anaesthesia produced by the intersection of economic and legal thought in the nineteenth century, about the politics and techniques of a tort class, about a feminist reading of a first-year casebook, about the Freedom of Information Act, about the fourth amendment and the public/private distinction, about the metonymics of sexual and legal repression and about cls and Wittgenstein. What could such a range of articles possibly share and what are "metonymics," anyway?

Skipping blithely over the dangers of proposing common themes, I want to argue that all of these Articles can usefully be seen as all dealing with false necessity. By "false necessity," I mean the apparent inevitability of existing arrangements, the way that "what is" gets converted into "what ought to be." I have argued elsewhere for the usefulness of seeing critical legal scholarship in this light, but for the moment my aim is only to bring out a tactical similarity in each of these Articles. The similarity is the attempt to show the political and other choices that are suppressed beneath the surface of the activity in question.

Duncan Kennedy uses an interpretation of Marx's Essay on The Fetishism of Commodities as the lead into a series of Essays that deal with the reification of "the market." Seen in this light, the interlocking activity of the classical (and neoclassical) lawyers and economists has something in common with the way Marx described the mystification of "value." The link is not that "its all a capitalist plot," but rather that, in both cases, the result is to imbue a system made by human beings with "fateful objectivity" and thus to conceal its actual malleability as well as insulating it from change.

Marx, Gramsci, Lukacs, Sartre, Melville, Kafka, Woolf, Vonnegut, Breton, (E.P.) Thompson, Gilligan, Dinnerstein, and Marbury v. Madison. We studied the Code of Professional Responsibility, compared Italian futurism to legal realism, argued about "comparable worth" and analyzed the internal logic of nuclear deterrence theories. We read Blackstone, (and Kennedy on Blackstone), as well as Coke, Bacon, Holmes, Cohen (Morris and Felix), Fuller, Hart, Hale, Ely, Tribe, Tushnet, Klare, Brest, Horwitz, Gabel, Michaelman, and Posner. (And if you don't know what half of these names mean, then you are in the same position most of us were in at the begining of the class).

The most important thing about the seminar, however, was not the number of famous scholars, live or dead, whose work we ingested. It was the way the seminar worked. There is too much to say about that, as well. But one point is worth making. This class, in its own little way, violated all the standard norms of law school discipline. ("You've got to have an instructor to keep things moving," "People with busy schedules only do the assignments that they will be punished for not doing," etc.) But it worked. 
My own Article is, as its title suggests, the anatomy of a torts course that I taught. My aim in writing it was to violate the implict ban against scholarship about teaching and, thus, to demonstrate the range of implicit messages about law, history, legal argument and professional ideology that are conveyed in the classroom. I take up Duncan Kennedy's themes of the reification of "the market," the impact of the public/private distinction, and the interlocking nature of legal and economic visions and relate them to tort doctrine as it is presented in a first year class. By juxtaposing a series of narratives about the class with an analysis of the things I was trying to teach, I have attempted to produce an example of "local theory," rather than merely talking about the desirability of such a thing. Included as an appendix to the Article is the analysis of legal arguments that I handed out to my class with the aim of teaching an indispensable skill while simultaneously demystifying legal discourse.

Mary Joe Frug's Essay, Re-Reading Contracts: A Feminist Analysis of a Contracts Casebook, continues the themes of feminist theory and of the politics of teaching. As teachers or casebook writers, we may imagine that our texts say just what they appear to; they speak in a calm monotone about the subjects we are studying, are "heard" to do so by everyone in their prospective audience, and convey no extraneous messages about the world or our conception of people within it. By describing a set of hypothetical readers, and then taking sections of the casebook and discussing them from various gendered perspectives, Mary Joe demonstrates that the gendered readings she describes can be the basis for different ways of understanding everything from ourselves to legal doctrine.

K.G. Worden's Article deals with the unconscious assumption that one moral "voice" is inherently suited to the study and practice of law. Drawing on the work of Roland Barthes and Carol Gilligan, K.C. uses a series of "microphenomenological accounts" or "stories" (pick your jargon) to show the suppression of the "female voice" in law school. From Barthes she takes the idea that the most powerful ideologies may be those that don't even appear to be ideologies-"that which goes without saying." Barthes' technique was to focus on these ideas and ideologies as they appeared in the most unlikely and "innocent" places-professional wrestling, guide books, photographs of a soldier saluting the tricoleur, the design of childrens' toys-and K.C. does the same for law schools. She looks at such phenomena as "double-bolding" in Gilbert's, the appropriate clothing for a moot court competition, and the implicit limits of classroom discussion. From Carol Gilligan she takes the idea of the "female voice"-a distinct approach to moral problems and to rea- 
soning in general which, Gilligan claims, has been ignored by theories of moral and psychological development. By combining the two techniques-Gilligan's model of "female voice" rationality and Barthes' phenomenological critique of ideology-K.C. can explore the internal politics of legal education in a way that appeals directly to our experience of life.

John Moon's Article takes up the question of the relationship between liberal state theory and the claim that law is neutral and objective. Taking the Freedom of Information Act as an illustration, he uses Duncan Kennedy's idea of "the fundamental contradiction" to expose both the central tasks of legal doctrine, and the recurring tensions that prevent it from fulfilling that task. The "fundamental contradiction between Self and Others" is a sort of algebraic version of liberal state theory. The recurrent tension between my need and my fear of others is going to be mediated by the state. The state will allow good interactions, grease the wheels of commerce, protect the polity, and it will also discourage bad interactions (criminal, or tortious). In other words, the state acts as a kind of filter between Self and Other, letting through only those kinds of contact which we wish to encourage.

But what is to prevent the state, itself, from becoming a nasty and threatening "Other"-dominating me, taking away my property and so on? It is precisely because the state has been given such an important role to play that it is an object of such fear in the liberal world view. The idea of objective, apolitical law is the conceptual device by which we are supposed to dissolve this fear. The state will be bound and restrained by the rule of law, and it in turn, will regulate my relationships with Others according to our respective legal rights. Thus, the success of the state's mediating role appears to depend on the viability of some kind of neutral legal interpretation, otherwise all those nasty fights between Self and Others are simply going to reappear as we consider which policy, right, interpretation, or interest, is going to win in the case at hand. John shows that the Freedom of Information Act is a classic example of the struggle to maintain some convincing version of this kind of apolitical legal interpretation. As we go through the statutory exemptions, all of the doctrinal techniques are trotted out-we have some "plain meaning," some "purposive interpretation," some "delimitation of spheres of power," and so on. Of course, these techniques are actually the ones acquired so painfully in first year (for details, see the articles by K.C., Mary Joe and myself) and so John's piece allows us to make the connection between the analysis of pedagogy and the ideological structure of legal argument. 
So the doctrinal methods described earlier as features of the first year experience, reappear as attempts to make law seem neutral and thus to deal with a basic issue in liberal state theory. John's claim is that we would be mistaken to rely on this conception of law and state; first, because we would fool ourselves into believing that we already had an adequate government disclosure system and, second, because we should be focusing instead on the contradiction that this legal theory is supposed to deny-in the same way that a patient undergoing analysis uses the surface structures of her mechanisms of denial to work out what it is that is really being denied. Once one sees the liberal picture of the hopes and fears of the polity as only one among many possible versions, one can begin to ask such questions as; are we right to focus so exclusively on the fear of public power? Aren't there excesses of "private" power that are potentially just as dangerous, but which are rendered invisible in the liberal vision of the world? Once again the central topic of the piece is the "false necessity" produced by a particular social and conceptual system-the way a particular view of the world simply makes some political conflicts invisible.

Don Pongrace's Article continues the discussion of the impossibility of contructing a system of neutral legal interpretation. Like John, he sees law as a mediating device, one that mediates not only between the state and the citizen, but also between conflicting visions of personality contained in liberal theory and worked out in legal doctrine. The Article examines the legal delimitation, in the context of fourth amendment doctrine, of the line between the "public" and "private" spheres of human activity.

We talk airily about the public sphere and the private sphere as though those mysterious entities were both self-defining and selfcontained. But, as is pointed out in some of the earlier Articles in the Symposium, this is far from being the case. For example, when juxtaposed with the state, the marketplace is supposed to be private, whereas, when juxtaposed with the family, the marketplace comes to be seen as the world of public, instrumental rationality, potentially dangerous to the "private," nurturing world of family and home. Don is dealing with an area of law that is conceived around, though by no means limited to, the vision of the family and the home (and, by analogy, the zone of privacy) as being fragile entities, in need of strong constitutional protection from a potentially intrusive state. Thus, because of both its conceptual framework and its history, fourth amendment doctrine is a uniquely suitable example of the enterprise of protecting a particular-albeit contradictory-vision of "the good life," as that vision is expressed in legal doctrine. 
In his introductory sections Don exposes the process by which particular methods of legal analysis come to be associated with particular legal/political aims. This happens on both a small scale (liberals used to think that formalism was inherently conservative, but now want to use formalist arguments to protect the legacy of the Warren court) and a large scale (the belief that only by having a neutral system for legal interpretation can we protect our constitutional rights). Using fourth amendment doctrine as the example, Don argues that the fixation on objectivity derives in part from the fact that our most basic political and legal concepts contain contradictory visions of human nature and of the good life, and that legal doctrine is supposed to freeze these contradictory conceptions in some miraculous harmony. He concludes by claiming that we would be better to renounce these pretensions of objectivity-both in our jurisprudence and in our practices of judicial appointment. Instead of having two contradictory pictures of judges (as beneficiaries of political patronage at, and neutral logicians after, appointment) we should take seriously the idea that judges are polemical social theorists, and try to make them good social theorists.

If Don Pongrace's Article examines the process by which conceptions of personality are objectified by the legal system, Judy Harris' Article deals with objectification and with law, from a slightly different angle. Judy focuses on metonymy, the figure of speech by which a part comes to stand for the whole. For example, "The Pentagon" comes to stand for the military institutions, people and political forces who carry on their "business" in that building, among others. Metonymy gets its power from the fact that a choice is concealed, the choice of which part to use to symbolize the whole. It is by analyzing this choice-by asking "what would you have to think, to think that this represented the essential element of the thing portrayed?"- that one can expose the "false necessity" conveyed by metonymy, whether it is used in legal doctrine or in casual conversation. The interesting thing is the realization that sexist labels for women and legal categorizations use the same rhetorical technique, are examples of the same figure of speech.

This is not, of course, to say that the sexist and the legal metonymies are equally reprehensible; it is merely to point out that they both conceal political choices in the same way, because they both have the same conceptual structure. Both take a totality (a person and a social conflict) and abstract out that which is taken to be "of the essence" given the implicit background choice made in that particular field of discourse. The sexist sees women as sexual objects, but the question of whether there are other, better, views of the 
world is foreclosed. The lawyer or judge sees the categories as already set up, and thinks that no choice is necessary to operate within them. "And, neither there is!" you might respond. But Judy argues that this is not the case. By using choice-of-law examples, she shows that the decision as to which law governs may depend on legal categorization. "Is this a contracts issue or a torts issue?" But what are the purposes, the choices behind the decision to divide the world into contract and tort? They may be entirely irrelevant to any of the policies or reasons that would make us want to give a case to jurisdiction $a$ or jurisdiction $b$. By coming at this familiar legal realist criticism of traditional conflicts analysis from a linguistic perspective, Judy exposes a link between legal and social criticism-the critique of reification.

Stephen Brainerd's piece concentrates on the relationship between Wittgenstein, cls, and structuralism. The description I have just given makes his Article appear to be the most "philosophical"and thus the most off-putting to those who aren't terribly sure who Wittgenstein was, or why they should care about structuralism. Both reactions would be misplaced, I think.

Why is Wittgenstein important? First, the way that he writes. Rather than lay out an abstract argument about the operation of language, Wittgenstein gives us hundreds of little numbered anecdotes, gnomic examples of the ways that language works, and the ways that it does not. Something in this procedure should be familiar to lawyers. I have frequently been puzzled by the question of why legal scholarship is now so in tune with the current preoccupations of philosophers and literary critics. I now think that the answer to this question is intimately connected to the familiarity of Wittgenstein's method. Lawyers are "good at" deconstruction because, rather than talking in the abstract about how texts are infinitely manipulable, they are actually engaged in the manipulating exercise. Seen in this light Wittgenstein has a connection to, of all things, the Socratic case-method, as well as to other rather more fancy philosophical movements-the idea of "local theory" mentioned at the end of this introduction, for example.

So the first interesting thing about Wittgenstein is his method-a vision of theory as a lot of little ideas that work. The second idea, and the one that Stephen concentrates on more heavily in his Article, is tied up with the notion of linguistic indeterminacy. We can get only so much out of the idea that the meaning of words is always shaped by the purposes for which they are being used. Why do words in fact seem more solid than this? What gives them the false 
objectivity on which legal formalism, for example, depends? To answer these questions one has to explore the ways that words are a part of the social construction of reality. Consider the cluster of meanings that surround the word "woman." To understand how sexist assumptions are incorporated into, and reproduced through, ordinary language usage, one has to think about the "forms of life," the "language games," the "structures of social reality," that speak through us when we "use" words. A lot of the most interesting critical legal studies work concentrates on making these conceptual structures visible, partly in an attempt to answer the question that I posed earlier-what are the structures that give social relations with no necessary form, or words with no essential meaning, their appearance of determinacy and necessity, their false objectivity?

The ironic significance of Wittgenstein's work is that it gives one some of the tools to answer this kind of question, but it also gives one the tools to undermine those same answers. I may claim that judges who operated within a belief structure called "classical legal thought" would feel compelled to frame an issue in a certain way, but if we want, we can demonstrate the incoherency of the concept of "classical legal thought" as easily as Wittgenstein can show that there is no core meaning to the word "game."

Thus, in trying to connect and compare Wittgenstein with the work of structuralists such as Levi-Strauss, who have been so influential on critical legal scholarship, Stephen is actually doing more than criticizing structuralism. He is carrying on a part of Wittgenstein's project that Wittgenstein, himself, mentioned but then neglected-the investigation of the politics of language and of thought, the ways that "the limits of my language are the limits of my world." So, if the connecting theme of this Symposium is the notion of "false necessity," the Articles written by Stephen Brainerd and Judy Harris can be seen as explorations of this theme as it appears in language, and in the very conceptual structures that we use to explain or criticize the social world. Stephen's piece is both a critique, and a critique of the method of critique itself.

But I can't simply stop here. Having used my description of Stephen's Article to raise one of the central problems in any theoretical enterprise it would be a tiny bit disingenuous to just leave it hanging there. So what does happen when you turn the critique on itself? And how do the. Articles in the Symposium deal with, or dissolve this question? One possibility is a lot of wailing and gnashing of teeth, a little high IQ whining, and a quietistic, apathetic approach to life and thought. "Nothing is certain, so it's certain I will do 
nothing." That kind of thing. Alternatively (taking the approach beloved of some law and economics devotees), one can struggle desperately to find some new, and temporarily comforting, source of "objectivity." It seems to me that the Articles in this Symposium have rejected both of these approaches. If I say instead that they can usefully be understood as attempts to construct some kind of "local theory," you shouldn't think that I am either specifying some unified method, or claiming that we can create objective descriptions of localities and particulars but not of generalities and universals.

By local theory, I mean several things, I suppose. There is the notion that by setting the theoretical issue up as an epistemological problem, we are being reductionists. There is just more to it than that. Take Mary Joe Frug's Essay. If we imagine that her aim is to circumvent or overcome and "epistemological problem" then there would be no point to her creation of, and argument with, different "readers," whose "reactions" to the piece deepen and contextualize her discussion. There would be no point because you cannot get around the epistemological problem of indeterminacy by multiplying your structures of analysis or explanation; the problem reappers in each one. But look at what is actually happening. It does seem to be true about the world that there are different groups of people with radically different "frames of reference," or what you will, that those people will approach her ideas in very different ways and that, by exposing the exclusion of still another "frame of reference," a gendered perspective, she is doing something useful. If our conception of an epistemological problem blinds us to the way in which her work is "better" than a mere lament about the impossibility of saying anything, then it seems that it is our notion of epistemological problems that is faulty. By dividing the world up into Objective truth and Subjective error, it excludes both the way that we actually think-using mulitple, contradictory structures for explaining what goes on-and the fact that it is important to "rediscover" the voices that have been completely excluded from the accepted way of discussing things.

K.C. Worden's Article provides an excellent example of this idea of the tasks of theory-she tries to expose, even if in a partial and incomplete way, the suppression of the "female voice" in legal education. But K.C.'s work also exemplifies another possibility opened up by the idea of local theory, the use of microphenomenologiescontextualized descriptions of some social or institutional setting. Again, if we cast things in epistemological terms, such an exercise does not make our theory "objective" by measuring it against the 
"facts," because there is no such thing as a pure description of "facts." Yet the need to convey the context of the criticism introduces new levels of complexity to what is going on, demonstrates the absurdly exclusionary character of the scholarly style, and produces the "exceptions" that cause her to challenge and refine her own thesis. This is not Karl Popper's notion of falsifiability, (thank goodness). But the existentialist, feminist, and phenomenological traditions of thought, the skeptic's injunction to "cherish your exceptions," and a desire to tell stories about what happens in the world, with the intention of changing it, seem to me to add up to something that is not a reconstitution of objectivity, but is worthwhile. Like Mary Joe's Essay and, in a sense, like all of the Articles in the Symposium, K.C.'s Article is not trying to create some method that denies contingency, but instead to expose the arbitrary exclusion of other voices-voices that haven't even been given the chance to confront their own contingency, because they haven't been heard at all. 